\title{
A BAKHTINIAN LESSON, OR THE HISTORY OF LITHUANIAN SOVIET NOVEL AS DESCRIBED BY ALGIMANTAS BUČYS
}

\author{
Marina Romanenkova \\ Mykolas Romeris University, Institute of Humanities, \\ Department of Applied Philology \\ Ateities 20, Vilnius, Lithuania \\ Telephone: (+370) 52714613 \\ E-mail: romanenkova@mruni.eu
}

Received on 31 August, 2013; accepted 21 October, 2013

doi:10.13165/SMS-13-5-4-07

\begin{abstract}
The paper deals with the analysis of the history of Lithuanian Soviet novel as represented by a literary critic Algimantas Bucys in his book "Novel and the Present Day" (1973, 1977). This book contains a strong Bakhtinian methodological introduction (it addresses Bakhtin's concept of the novel) and extensive quotes from Bakhtin's book "Epic and Novel", in which the novel concept is introduced. Bakhtin's text was very little known and hard to find back in the 1960s. As it is obvious from the analysis, Bakhtin's theory plays an ambiguous role in Bucys' history of the national novel. On the one hand, Bakhtin's theory provides theoretical grounds for the novelization of genres and is a suitable methodology for research into Lithuanian novel. On the other hand, Bučys uses a dogmatic type of analogy, and the analysis itself is based on comparing rather than on interpretation.
\end{abstract}

Keywords: M. Bakhtin, A. Bučys' book "Novel and the Present Day", Lithuanian Soviet novel, Bakhtinian methodology.

Socialinių mokslų studijos / Societal Studies

(C) Mykolo Romerio universitetas, 2013

(C) Mykolas Romeris University, 2013
ISSN 2029-2236 (print), ISSN 2029-2244 (online) http://www.mruni.eu/lt/mokslo_darbai/SMS/ http://www.mruni.eu/en/mokslo_darbai/SMS/ 


\section{Introduction}

All theoretical concepts have emerged in a certain historical situation and are connected to it and serve as an ideological device for adapting the individual and the human condition to each other. This is entirely true for M. M. Bakhtin's legacy. It cannot be comprehended beyond the context of his biography and the destiny of his generation. Like many of his compatriots (including the scholars), Bakhtin was a hostage of the historical situation. He spent three decades in exile: away from both capitals, he was almost deprived of all contacts with fellow scholars and of the possibility to publish his works ${ }^{1}$. He spent his whole life in the situation of unfreedom, and this, of course, left its imprint on his professional views, namely, the basics of his methods of research, such as the "author-character" discourse, historical poetics of genre or the philosophy of language were influenced by such situation in many respects.

Hence, it is not by coincidence that many modern researchers tend to treat Bakhtin's legacy as a unique "paradigm of thought", the starting point and the focal issue, of which is a situation of a secluded consciousness, an agent of two mighty communicative processes of the "small" and the "big" times of culture ${ }^{2}$, a part of a "larger-scale ideological project: a creation of the history of an individual voice"3.

In this respect, modern reception of Bakhtin's legacy is focused on "one of the most dolorous issues of reading Bakhtin's works" - the issue of the feeling of place and time having been lost, those places and times, in which texts were created ${ }^{4}$.

During the several last decades, the methodological element of Bakhtin's legacy has been indeed in demand, and, yet, it has been least researched. "The best evidence to the fact of Bakhtin being beyond his own texts is a reader's impression that they lack 'methodology', in spite of all that has been written exactly about a Bakhtinian methodology of humanities"5. To be aware of the ways of "modernization" of Bakhtinian concepts is a productive trend apt to adjust the "Bakhtinian approach"6 to the present day issues of the literary criticism.

1 Popova, I. L. Pochti ,yubilejnoe': zamechanie k desjatiletiyu vyhoda 5-go toma Sobranija sochinenij M. M. Bakhtina [Almost an Anniversary Edition: Remarks on the Tenth Anniversary of the Publication of the Fifth Volume of M. M. Bakhtin's Works]. Novoe literaturnoe obozrenie [New Literary Review]. 2006, 3 (79); Griffits, T.; Rabinovich, S. Tretij Rim [The Third Rome]. Sankt-Peterburg: Ivan Limbakh, 2005.

2 Tiupa, V. I. Bakhtin kak paradigma myshlenija [Bakhtin as a Paradygm of Thought] [interactive]. Novosibirsk: Virtual Chair of NSU, 1996 [accessed on 31-08-2013]. <www.lit-mp.ru/.../ bkakpar.html>.

3 Griffits, T.; Rabinovich, S., supra note 1, p. 318.

4 Popova, I. L., supra note 1, p. 51.

5 Isupov, K.G. Uroki M. M. Bakhtina [M. M. Bakhtin's Lessons]. M. M. Bahtin: pro et contra. Lichnost' $i$ tvorchestvo M. M. Bahtina $v$ otsenke russkoy i mirovoy gumanitarnoy mysli [M. M. Bakhtin: Pro Et Contra. M. M. Bakhtin's Personality and Works and Their Appraisal in the Russian and World Humanitarian Thought]. Tom I. Sankt-Peterburg: RCHI, 2001, p. 12.

6 Markovich, V. O Bakhtine ,podlinnom' I Bakhtine, realnom [Of the Genuine Bakhtin and the Real Bakhtin]. Novoe literaturnoe obozrenie [New Literary Review]. 79: 40. 
However, history shows some examples, when Bakhtinian methodology was used word for word and when the attempts to achieve a universal result led to misrepresentations in certain "histories" of national literatures. Back in the late 60 s - early 70 s of the 20th century, Bakhtin's theory of the novel was still accepted as new and attractive and to some extent an object of disputes. Of course, one of the focal issues was whether this theory was suitable for research. This is why a monograph by A. Bučys can be hardly overestimated. His book "The Novel and the Present Day. The Establishment and the Development of the Lithuanian Soviet Novel" was well-known in the USSR. It was first published in Lithuanian in 1971 and amended and republished in 1973. In 1975, it was awarded the State Prize of Lithuanian Soviet Socialist Republic. In 1977, both the second edition and the Russian translation ${ }^{7}$ of this book were published.

Theoretical and methodological bases are not directly specified in the book, and there are but a few references to its theoretical background - the works by "a wellknown Soviet literary critic M. Bakhtin"s. Nevertheless, the text is so much filled with specifically Bakhtinian terms and expressions, that there is no doubt left concerning the methodological orientation of the book. Still, the subheading of the monograph reads "the establishment and the development of the Lithuanian Soviet novel", and through it certain new connotations irrelevant for Bakhtinian discourse are made absolutely obvious. The Lithuanian SSR State award of 1975 later was explained in Lithuanistical studies as "ideologically determined".

This paper aims at analyzing how Bučys succeeded to apply Bakhtin's theory of the novel to the Soviet present day, what language and what devices he used to achieve this purpose. Also, the author of this research is interested in why this theory and history of the Lithuanian Soviet novel happened to be so short-lived, notwithstanding the fact that it was based on Bakhtinian theory.

\section{Getting the Answers}

Bučys managed to apply Bakhtin's theory of novel to the Soviet present day due to altering the meaning of several key terms of Bakhtin's theory. He adopted this methodology word for word and superimposed it on the contemporary literary and historical material. Thus, he constructed a history of the Soviet Lithuanian novel with the novel of the inner

7 Bučys, A. Roman i sovremennost. Stanovlenie i razvitie litovskogo sovetskogo romana [Novel and the Present Day: The Establishment and Development of the Lithuanian Soviet Novel]. Moskva: Sovetskij pisatel, 1977.

8 Bučys, A. Romanas ir dabartis: lietuviu tarybinio romano raida iki $1970 \mathrm{~m}$. (žanro problemos) [Novel and the Present Day: the Development of the Soviet Novel before 1970 (Genre Issues). [English translation is missing]. 2nd issue. Vilnius: Vaga, 1977, p. 46.

9 Baliutytè, E. Sovietmečio lietuvių literatūros kritika kaip socialinis reiškinys [Soviet period Lithuanian literray criticism as a social phenomenon]. L [English translation is missing]. Lituanistica. 2003, 1 (53): 113. 
monologue at its final stage of evolution. A more detailed outline of how it was done is presented next, revealing four methodological grounds of Bučys' work.

First, when Bakhtin characterized the struggle between the "epic" and the "novelistic" generative literary principles as a new trend of European prose, he appealed to the antiquity, in which he outlined a specific domain - serio-comic genres, embracing Socratic dialogue and Menippean satire. He did it in order to reveal their genetic role for the emergence of the future genre of the novel. It is important to mention that Bakhtin favoured this methodological approach: "For the correct understanding of a genre $\langle\ldots\rangle$ it is necessary to return to its sources"10. A weak, although clear echo of such Bakhtinian-style "digression into the realm of the history of genres"11 is heard in Bučys' book in the chapter with a representative title "At the Source" and also in the chapter "Traditions and Theories"12. In this chapter, it is possible to hear the echoes of the impressive Chapter 4 titled "Characteristics of Genre and the Composition of Plot in Dostoevsky's Work" from "Problems of Dostoevsky's Poetics" by Bakhtin. There are two peculiarities of Lithuanian prose, which have doomed the "genre essence" of the traditional genres and which are regarded by Bučys as rough prerequisites of the future Lithuanian novel: a somewhat pronounced independence of the origin and an undoubtedly pronounced differentiation of the prose genres ${ }^{13}$.

Second, Bakhtin referred to "the absence of temporal perspective in ancient society" ${ }^{\prime 4}$, when he needed a reference point for encountering new genres. He argued that the global reorientation of genres occurred in the Renaissance. Similarly, the emergence of the Soviet Lithuanian novel, according to Bučys, occurred during the "transition from the capitalist system to the socialist one"15. As far as early Lithuanian novels (since 1904) and "pre-Soviet" prose, as such, used to express "counter-humaneness of the dominant (bourgeois - M. R.) regime" 16 , the point, when the marks of the "modernity" have manifested themselves in national literature, was set in 1940, when Lithuania became a Soviet republic and a part of the USSR.

In an attempt to support this viewpoint, a Lithuanian literary critic presented a kind of interpretation of Bakhtin's ideas, which violated the historicism of the very conception of the novel, and so it could be used as a universal method for studying the novel. A new Lithuanian novel was to be generated by the "yet unshaped existence" and the novel's "heavy dependence on the present day of which it was an offspring"17. Writers were then supposed to elaborate this very interesting, new and at the same time extremely complex

10 Bakhtin, M. Problems of Dostoevsky's Poetics. Edited and Translated by Caryl Emerson. Minneapolis: University of Minnesota Press, 1999, p. 106.

11 Ibid., p. 137.

12 Bučys, A., supra note 7, p. 37-89.

13 Ibid., p. 39-40.

14 Bakhtin, M. The Dialogic Imagination: Four Essays. Austin: University of Texas Press, 1981, p. 40.

15 Bučys, A., op. cit., p. 11.

16 Ibid., p. 142.

17 Bučys, A., supra note 7, p. 46. 
issue of the artistic mastering of the present day reality. This task required some notable reforms in the structure of the traditional post-war novel ${ }^{18}$.

Up to the 1960s, the development of the novel, as Bučys summed up, was not a trivial process, but Lithuanian novelists (e.g., E. Simonaitytė, B. Sruoga, J. Baltušis, M. Sluckis) profited from this experience: they managed to create "a peculiar kind of novel written in a new manner"19. Thus, in autobiographical stories by Simonaityte, "ironical, humorous people's word <...> was exactly what made it possible to combine white and black, elevated and low, serious and comical... By this means only was it possible to represent, for instance, a party organizer as a human and not just a 'benchmark' <... So the narration was made closer to the reality" ${ }^{20}$. Bučys discovered "a lack of epic distance" in the famous novel entitled "Forest of Gods" by Sruoga: "The choice of the narrative style - comical depiction - was predefined by the reality itself, and it was not the author of the "Forest of Gods" who chose the style to depict the reality"21. The point here is the "plane of comical (risorial) depiction, specific", according to Bakhtin, for both temporal and spatial planes ${ }^{22}$. In the representation of Nazis, grotesque elements ${ }^{23}$ prevail: "the narrator's point of view, his rich spiritual culture and intellect make for an uncompromising "denunciation" of the "men in power" at the camp <...>"24. Ironical depiction ${ }^{25}$ of the material lives of prisoners (once in the text Bučys called it the "corporal" lives, using the quotation marks but without references) is in fact ambivalent: "values and trifles", "respect and contempt", "vice and virtue" are all to be found here.

Also, Bučys noted the "creation of stylistic multiplicity" in the works by M. Sluckis, written in 1950s, and in the novel called "Sold Summers" by J. Baltušis, who, according to Bučys, found a "special meaning of the new narrator's 'point of view' occupied by not an 'all-knowing author' (quotation marks are there, but there is no reference again! - M. R.), but an ordinary character, a young herdsman" 26 .

Third, Bakhtin's discourse is full of implications, namely, the historical time and place are implied in the imagery of epic and novel. Unlike epic "as a genre that has not only since completed its development, but one that is already antiquated"27, the novel is marked by properties, such as vitality and openness, and they grant its rebirth and renewal "at every new stage in the development of literature and in every individual work of a given

Bučys, A., supra note 7, p. 183.

Bučys, A., op. cit., p. 192.

20 Ibid., p. 99-100.

21 Ibid., p. 102.

22 Bakhtin, M. M. Ehpos i roman (o metodologii issledovanija romana) [Epic and Novel (Toward a Methodology for the Study of the Novel)]. Voprosy literatury i ehstetiki [Issues of Literature and Aesthetics]. Moskva: Khudozhestvennaja literatura, 1975, p. 466.

"In this plane (risorial one) (...) the object is split, uncovered (deprived of all its hierarchical decorum) (...)". Ibid., p. 467.

24 Bučys, A., op. cit., p. 101.

25 In Bakhtin's terms, "contemporization”. Bakhtin, M. M., supra note 21, p. 464, 467.

26 Bučys, A., supra note 7, p. 117.

27 Bakhtin, M., supra note 13, p. 3. 
genre"28. A Lithuanian critic used an image, too. One of such images was a volcano, in the crater of which "various elements, conventions of genres exist in the constant movement and mutation, ready to form in different patterns, each for a certain work of art" 29 .

Fourth, Bučys paid most attention to a contemporary novel, as one of the structural elements emerged in the 1960s and it is known as a novel of inner monologue. In the same way as Bakhtin, who considered Dostoevsky's novel as a turning point for the genre ("A depiction of an individuality requires first of all a radical shift in the position of the author-depictor towards "you". It is required not to notice some new objective traits, but to change the very artistic approach to the person being depicted, to alter the frame of reference ${ }^{30}$ ), a Lithuanian critic focused on the teller's viewpoint, too. Bučys explained his concept of a freely developing personality in the following way: "The words were demanded by the character himself". Subsequently, the Bakhtinian principle of a "requirement of an individual's free self-disclosure"31, which requires a special type of inter-personal dialogue (dialogical polyglotism of a novel), was turned by Bučys into a mere ideological cliché, "And indeed in those years (1960s - M. R.) the loudly voiced communist principle 'everything for people and everything for the sake of people' was not just being declared or feebly illustrated, but became the very foundation of the concept of a personality" 32 . However, contrary to the critic's ideological optimism, the characters of the novels by Mikelinskas, Bubnys, Sluckis did not reach the prescribed by the theory "condition as a man" 33 . Bučys himself noted that in the 1970s, there "appeared quite a lot of characters who do nothing but think and talk" ${ }^{4}$. He understood it as a weakness of writers as artists: "Lithuanian novelists still rarely succeed in depicting a character in free development in the context of great problems of being. Instead they tend to leave the character in the world of everyday problems and minor moral conflicts" ${ }^{35}$.

\section{Conclusion}

A. Bučys' conception is an ambiguous attempt for the creation of a historical overview of the national novel. On the one hand, it appears to be a proper theoretical pattern of genre novelization. On the other hand, as a methodology of studying a Lithuanian novel, it

Bakhtin, M., supra note 9, p. 106.

Bučys, A., op. cit., p. 159-160.

Bakhtin, M. M. Plan dorabotki knigi "Problemy poetiki Dostoevskogo" [Draft of Modifications to the "Problems of Dostoevsky's Poetics"]. Kontekst 1976 [Context 1976]. Moskva: Nauka, 1977, p. 316.

Bakhtin, M. M. K filosofskim osnovam gumanitarnyh nauk [Towards the Philosophic Grounds of the Humanities]. In Bakhtin, M. M. Sobranie sochineniy $v 7 t$. [Collected Works in 7 Volumes]. 5th volume. Moskva: IMLI, Russkie slovari, 1997, p. 7.

Bučys, A., supra note 7, p. 154.

Bakhtin, M. M., supra note 13, p. 37.

Bučys, A., supra note 7, p. 286.

Bučys, A., supra note 7, p. 200. 
emerged in a dogmatic form of analogy. This approach made it possible to use Bakhtinian system of notions of "big time".

On the one hand, Bakhtin's theory surely is a theoretical pattern of novelization of genres. On the other hand, as a methodology suitable for research into the Lithuanian novel, it was dealt by Bučys as a dogmatic type of analogy. Bučys used the Bakhtinian notion of the "big time", but this resulted not in incorporation of the Lithuanian novel into the universal novelist trend, but in actualization of the Soviet context of interpretation of history. Bučys analyzed the near past of the Lithuanian novel to trace its development up to the triumphant present day - the Lithuanian novel of the inner monologue. Also, he blueprinted a predicted (expected) future of the Lithuanian novel (although this plan did not appear in reality). Bučys' book "Novel and the Present Day" is unfortunately not in demand today. Already in the 1990s, a well-known Lithuanian literary critic V. Kubilius wrote with sympathy about new trends in the 1970s literary criticism related to the "opposition to the Soviet lifestyle and to the stagnation of the thought" ${ }^{\text {, which }}$ was due to the shift of reference points. It was not the "naked ideological position in need for corrections", which got into the focus of the criticism, but the "aesthetic reality, the meanings of which were not limited to a single solution" 37 . In the context of this argumentation, Kubilius dedicated several lines to the Bučys' book. Kubilius treated the position of a critic in a slightly ironical key, using Bakhtinian allusions: "The critic was not any more judging, but more likely perceived himself to be minded like the author, to live in the zone of his issues, images and even his style (italicised by the author - M. R.), to create the ideological bulwark for his creative work. Sometimes even a demonstrative dismissal of his value solutions could turn possible. (A. Bučys. Novel and the Present Day. 1973)"38. It seems that Kubilius implied a demonstrative manner, in which Bučys made use of Bakhtinian methodology without any attempt to consider the Lithuanian national and cultural context. Due to historical causes and the context of the humanities of the 1970s, a Lithuanian critic as well as his colleagues was not able to realize the degree of the "intensity of Bakhtin's style" 39 .

So, Bakhtin's notions used by Bučys lost their aptitude for the creation of the "specifically Bakhtinian semantic unity" (L. Gogotishvili). Therefore, they have to be treated within the context of this book, keeping in mind its author's goals. Thus, it becomes obvious that Bučys' book formally follows the Bakhtinian methodology, but in fact it violates the theory and misrepresents the history of the Lithuanian literature of the Soviet time.

36 Kubilius, V. XX amžiaus literatūra: Lietuviu literatūros istorija. Kritika. 3rd edited and supplemented issue. Vilnius: Alma littera, Lietuvių literatūros ir tautosakos institutas, 1996, p. 686.

38 Ibid.

39 Isupov, K. G., supra note 5, p. 369. 


\section{References}

Bakhtin, M. M. Ehpos i roman (o metodologii issledovanija romana) [Epic and Novel (Toward a Methodology for the Study of the Novel)]. Voprosy literatury $i$ ehstetiki [Issues of Literature and Aesthetics]. Moskva: Khudozhestvennaja literatura, 1975, p. 447-483.

Bakhtin, M. M. Plan dorabotki knigi "Problemy poehtiki Dostoevskogo" [Draft of Modifications to the "Problems of Dostoevsky's Poetics"]. Kontekst 1976 [Context 1976]. Moskva: Nauka, 1977, p. 295-316.

Bakhtin, M. M. The Dialogic Imagination: Four Essays. Austin: University of Texas Press, 1981.

Bakhtin, M. M. K filosofskim osnovam gumanitarnyh nauk [Towards the Philosophic Grounds of the Humanities]. Sobranie sochinenij $v 7$ tomah [Collected Works in 7 Volumes]. 5th volume. Moskva: IMLI, Russkie slovari, 1997, p. 386-401.

Bakhtin, M. M. Problems of Dostoevsky's Poetics. Edited and Translated by Caryl Emerson. Minneapolis: University of Minnesota Press, 1999.

Baliutytè, E. Sovietmečio lietuvių literatūros kritika kaip socialinis reiškinys [Soviet period Lithuanian literray criticism as a social phenomenon] [English translation is missing]. Lituanistica. 2003, 1 (53): 108-120.

Bučys, A. Roman i sovremennost. Stanovlenie $i$ razvitie litovskogo sovetskogo romana [Novel and the Present Day: The Establishment and Development of the Lithuanian Soviet Novel]. Moskva: Sovetskij pisatel, 1977.

Bučys, A. Romanas ir dabartis: lietuviu tarybinio romano raida $i k i 1970 \mathrm{~m}$. (žanro problemos) [Novel and the Present Day: the Development of the Soviet Novel before 1970 (Genre Issues). [English translation is missing]. 2nd issue. Vilnius: Vaga, 1977.

Gogotishvili, L. A. Kommentarij k tekstu: M. M. Bakhtin, K filosofskim osnovam gumanitarnyh nauk [Comments to the Text: M. M. Bakhtin Towards the Philosophic Grounds of the Humanities]. In Bakhtin, M. M. Sobranie sochinenij v 7 tomah [Collected Works in 7 Volumes]. 5th volume. Moskva: IMLI, Russkie slovari, 1997, p. 386-401.

Griffits, T.; Rabinovich, S. Tretij Rim [The Third Rome]. Sankt-Peterburg: Ivan Limbakh, 2005.

Isupov, K. G. Uroki M. M. Bakhtina [English translation is missing]. M. M. Bakhtin: pro et contra. Lichnost i tvorchestvo M. M. Bakhtina v ocenke russkoj $i$ mirovoj gumanitarnoj mysli [M. M. Bakhtin's lessons // M. M. Bakhtin: Pro et Contra. M. M. Bakhtin's Personality and Work and Their Evaluation in Russian and World Humanitarian Thought. ${ }^{*}$. [English translation is missing]. Tom I. SanktPeterburg: RCHI, 2001, p. 7-44.

Kubilius, V. XX amžiaus literatūra: Lietuviu literatūros istorija. Kritika. 3rd edited and supplemented issue. Vilnius: Alma littera, Lietuvių literatūros ir tautosakos institutas, 1996, p. 678-704.

Markovich, V. “O Bakhtine 'podlinnom' i Bakhtine 'realnom"' [Of the Genuine Bakhtin and the Real Bakhtin]. Novoe literaturnoe obozrenie [New Literary Review]. 2006, 3 (79): 39-49. 
Popova, I. L. Pochti 'yubilejnoe': zamechanie $\mathrm{k}$ desjatiletiyu vyhoda 5-go toma Sobranija sochinenij $\mathrm{M}$. M. Bakhtina [Almost an Anniversary Edition: Remarks on the Tenth Anniversary of the Publication of the Fifth Volume of M. M. Bakhtin's Works]. Novoe literaturnoe obozrenie
[New Literary Review]. 2006, 3 (79): $50-55$.

Tiupa, V. I. Bakhtin kak paradigma myshlenija [Bakhtin as a Paradygm of Thought] [interactive]. Novosibirsk: Virtual Chair of NSU, 1996 [accessed on 31-08-2013]. <www.lit-mp.ru/.../ bkakpar.html>.

\title{
BACHTINO PAMOKA: A. BUČIO LIETUVIŲ TARYBINIO ROMANO „ISTORIJA“
}

\author{
Marina Romanenkova
}

Mykolo Romerio universitetas, Lietuva

Santrauka. Straipsnyje analizuojama lietuviu tarybinio romano „istorija“, kuri pateikta lietuviu literatūros kritiko Algimanto Bučio knygoje „Romanas ir dabartis“ (1973, 1977). Démesys atkreipiamas i labai stiprų šioje knygoje vyraujantị Bachtino metodologini prada (M. Bachtino romano koncepcijos taikymas), taip pat $i$ tai, kad A. Bučys pateikia itin mažai tiesioginių citatų iš mažai kam prieinamos ir XX a. septintajame dešimtmetyje žinomos M. Bachtino knygos „Epas ir romanas“.

A. Bučio knygos analizès imtasi turint tikslą atsakyti i šiuos klausimus: kaip A. Bučiui pavyko su M. Bachtino romano teorija patikrinti tarybine dabartį. Kokia aprašomoji tokios literatūros istorijos kalba, kokia büdų ir argumentų sistema? Kodèl lietuviu tarybinio romano teorija ir istorija, lietuviu kritiko pateikiama naudojantis Bachtino koordinatemis, orientuotomis $\dot{i}$ "didelio laiko" perspektyvą, pasirode esanti tokia neilgaamžé? Ieškant atsakymo i pirmaji klausima pavyko nustatyti, kad kuriant nacionalines romanistikos istorija M. Bachtino romano koncepcijai A. Bučio knygoje tenka dvejopas vaidmuo. Viena vertus, ji pateikiama iš esmès kaip teorinis žanru romanizacijos kanonas. Kita vertus, kaip lietuviu romano tyrimo metodologija A. Bučo knygoje ji igavo dogmatiška analogijos formą, jai buvo priskirta analizès, pagristos ne interpretacija, o prilyginimu, forma. Šis büdas leido A. Bučiui naudojantis Bachtino „didelio laiko“terminu sistema ne tiek susieti lietuviu romana su universalia „romano“ "tendencija, kiek aktualinti tarybini suvokimo kontekstą: išanalizuoti „vidinio monologo "lietuviu tarybinį romano „artimiausia praeiti“ privedant ja iki „dabarties" triumfavimo, taip pat nužymèti lietuviu romanistikos „numatoma (pageidaujama) ateitic“ (kuri, reikia pripažinti, būtent tolesnès literatūros proceso plètros perspektyvoje nepateisino prognoziu). Atsakant i antraji klausima, ar šiandien dar aktuali knyga „Romanas ir dabartis“, deja, tenka pripažinti, kad ne. Dèl istorinių priežasčiu ir moksliniu aplinkybiu joje buvo iškreiptas ar net prarastas ne tiktai Bachtino romano diskursas ir pačios teorijos „giluminis metaforiškumas", bet ir aprašymo kalba, metodologiniai büdai. A. Bučio vartojami terminai knygos kontekste netenka gebejjimo kurti „specifiškai Bachtino prasminị įkūnijima“" (L. Gogotišvili) ir juos reikia traktuoti remiantis tais tikslais, kuriuos sau kelia tarybinès 
literatūros tyréjas, tad tampa akivaizdu, kad knyga, formaliai grindžiama Bachtino metodologija, pažeidžia ir pačią teoriją, taigi ir iškraipo minèto laikotarpio lietuvių literatūros istorija.

Reikšminiai žodžiai: M. Bachtinas, A. Bučio knyga „Romanas ir dabartis“, lietuviu tarybinis romanas, Michailo Bachtino metodologija.

Marina Romanenkova, Mykolo Romerio universiteto Humanitarinio instituto Taikomosios filologijos katedros docentè. Mokslinių interesų kryptys: lyginamieji literatūros tyrimai, XX a. rusų literatūra, literatūros teorija, rusų kalbos kaip užsienio kalbos metodika.

Marina Romanenkova, Mykolas Romeris University, Institute of Humanities, Department of Applied Philology, Associate Professor. Research interests: comparative literature, Russian literature of the 20th century, literary theory. 